\title{
Terapi Komplementer Relaksasi Otot Progresif Jacobson Untuk Menurunkan Tekanan Darah Pada Penderita Hipertensi
}

\author{
Rosiana $^{1}$, Diah Ratnawati ${ }^{2 *}$ \\ ${ }^{1,2}$ Fakultas Ilmu Kesehatan, Universitas Pembangunan Nasional Veteran Jakarta \\ *Email: ratnawatidiah@yahoo.co.id
}

\begin{abstract}
Background: Hypertension is a condition of an increase in blood pressure from the normal range of $120 / 80 \mathrm{mmHg}$. If there is no action is taken to reduce blood pressure, it can lead to serious complications. Jacobson's progressive muscle relaxation can be used as an action in reducing high blood pressure. Aims of this study is to analize effect of Jacobson's progressive muscle relaxation to decrease blood pressure. Methods: This research used a quasi-experimental method and a sample of 16 respondents. JPMR Therapy is carried out for three weeks with three times each week. The action is carried out for 30 minutes. Blood pressure measured by spyghnomanometer before and after intervention. Results: the result of this intervention showed a P-Value is 0,0001, which means blood pressure decreases after intervention. Conclusion: This intervention is proven to be a complementary therapy for hypertension suffers. For this intervention to have the maximum results for blood pressure reduction, patients must routinely intervene every day along with the ingestion of the drug. The need for more research is how long normal blood pressure persists with JPMR.
\end{abstract}

Keywords: blood pressure, hypertension, jacobson, relaxation

\section{PENDAHULUAN}

Tekanan darah adalah penekanan pada darah secara paksa yang ditujukan untuk melawan dari dinding pembuluh darah (AHA), 2016). Salah satu permasalahan dari tekanan darah yaitu meningkatnya teknana darah yang disebut dengan hipertensi (WHO, 2019). Hipertensi merupakan analogi dari pada tekanan bagi darah untuk melewati dinding pembuluh darah secara berlebih (AHA, 2016). Secara garis besar seseorang akan dinyatakan hipertensi apabila saat pemeriksaan hasil dari sistolik di atas $120 \mathrm{mmHg}$ dan diastolik di atas 80 $\mathrm{mmHg}$ (Stafford dkk, 2018). Hipertensi berada pada kategori penyakit yang tidak dapat menular (Kementrian Kesehatan Republik Indonesia, 2013). Hipertensi merupakan suatu faktor resiko dari penyakit yang menyerang pembuluh darah (Khandare, Sabuwala, Palekar, \& Kuma, 2017). Penyakit ini sering disebut sebagai penyakit yang membunuh secara perlahan dengan jumlah penderita yang tinggi (Khandare dkk., 2017).

Hipertensi masuk ke dalam penyakit yang memiliki jumlah penderita yang tinggi. Berdasarkan data World Health Organization (WHO) tahun 2015 didapatkan hasil bahwa 1,5 milyar penduduk dunia memiliki hipertensi. Hal ini memiliki arti bahwa satu dari tiga penduduk di dunia terdiagnosis hipertensi (Kemenkes, 2019). Sebanyak 80 juta masyarakat di Amerika dengan usia lebih dari 20 tahun dimana satu dari tiga orang memiliki penyakit ini. Prevalensi penderita hipertensi di Kanada adalah $25 \%$ pada rentang usia dewasa (C dkk., 2018). Provinsi di Indonesia yang memiliki wilayah tertinggi penderita hipertensi adalah Sulawesi Utara dengan jumlah penderita 13,2 \% (Kemenkes, 2018). Bukan hanya jumlah penderita yang tinggi dari hipertensi, namun penderita hipertensi juga memiliki rentang usia yang berbeda - beda. 
Penderita hipertensi juga memiliki rentang usia yang berbeda di Indonesia. Masa sekarang dapat menunjukan bahwa hipertensi bukan hanya dialami oleh lansia. Penderita hipertensi di Indonesia terdiri dari berbagai golongan usia di mulai ketika usia lebih dari 30 tahun (Kemenkes, 2019). Pada usia $31-33$ tahun jumlah penderita sebanyak $31,6 \%$. Usia 45 - 54 tahun memiliki penderita sebanyak 45,3\%. Rentang usia $55-64$ tahun sebanyak $55,2 \%$ penderita (Kemenkes, 2019). Kondisi ini diperlukan adanya penanganan baik dari tenaga kesehatan maupun lingkungan setempat untuk melakukan pencegahan hipertensi.

Penderita hipertensi yang tinggi baik di Indonesia maupun di luar Indonesia menandakan bahwa hipertensi memerlukan penanganan dan pencegahan agar penderita dapat menurun. Keperawatan sebagai integral pelayanan kesehatan profesional. Ilmu keperawatan mampu untuk memberikan asuhan kepada individu keluarga maupun masyarakat yang sehat maupun sakit merupakan tenaga yang ideal untuk membantu mengurangi permasalahan hipertensi di keluarga (Hernilawati, 2013).

Keperawatan sebagai penyedia layanan kesehatan baik kepada individu, keluarga, maupun komunitas merupakan sosok yang tepat dalam penanggulangan hipertensi di lingkungan masyarakat. Sebagai penyedia layanan kesehatan, keperawatan komunitas dapat bergerak secara langsung untuk membantu individu dan keluarga mencapai derajat kesehatan dari hipertensi (Hernilawati, 2013). Intervensi yang diterapkan sebagai keperawatan komunitas haruslah memiliki banyak manfaat dan mudah dilakukan (Hernilawati, 2013). Salah satu bentuk intervensi yang dapat dilakukan untuk pengurangan dari derajat hipertensi pada individu di keluarga adalah relaksasi otot progresif jacobson.

Relaksasi otot progresif Jacobson merupakan program relaksasi yang ditujukan untuk pengurangan stres dan penurunan tekanan darah pada penderita hipertensi. Prinsip tindakan dari relaksasi ini adalah dengan melakukan penahanan pada otot kemudian merileksasikan otot (Guy's \& Thomas, 2019). Seseorang yang melakukan relaksasi ini akan merasakan perbedaan saat mengencangkan otot kemudian melepaskan ketegangan ototnya (Kesoema, Chasani, \& Handoyo, 2016). Relaksasi ini ideal dilakukan untuk membantu dalam terapi penurunan tekanan darah dikarenakan mudah dilakukan di rumah dan murah (Khandare dkk., 2017).

Berdasarkan hasil studi pendahuluan yang dilakukan pada tanggal 19 Januari 2020 di RW 15 desa Ragajaya Kecamatan Bojonggede. Hasil studi pendahuluan menunjukan bahwa pada terdapat 17 penderita hipertensi dengan tekanan sistolik lebih dari $130 \mathrm{mmHg}$ dengan rentang usia 45 - 60 tahun. Hasil tersebut didapatkan dari pemeriksaan tekanan darah. Hasil ini menunjukan adanya penderita hipertensi di lingkungan RW 15. Hal ini menunjukan bahwa perlunya intervensi kepada penderita secara langsung untuk menurunkan tekanan darah.

Hasil dari penjelasan yang telah dijabarkan sebelumnya mengenai hipertensi di masyarakat serta keluarga maka penulis telah menetapkan intervensi penurunan hipertensi. Penelitian telah menunjukan bahwa relaksasi otot progresif Jacobson ideal untuk diterapkan di keluarga. Penulis memutuskan untuk melakukan implementasi berupa relaksasi 
otot progresif Jacobson pada penderita hipertensi yang bertujuan untuk mengetahui pengaruh dari JPMR terhadap penurunan tekanan darah penderita hipertensi.

\section{METODE PENELITIAN}

Penelitian ini menggunakan metode kuantitatif dengan desain quasi experimental pre test and post test. Pengukuran tekanan darah dilakukan sebelum dan sesudah dilakukan intervensi berupa relaksasi otot progressif Jacobson (JPMR). JPMR dilakukan sebanyak satu kali pada tiap 9 kali pertemuan (tiga kali seminggu dalam tiga minggu), dengan durasi $20-30$ menit pada setiap pertemuan. Pengukuran tekanan darah menggunakan sphygmomanometer manual. Tekanan darah yang dibandingkan adalah tekanan darah sebelum dan sesudah tindakan serta perbandingan tekanan darah hari pertama dengan hari terakhir. Gerakan pada relaksasi JPMR berjumlah 17 gerakan yang SOP diambil dari Guy's \& Thomas, (2019).

Responden pada penelitian ini terdiri dari 16 respoden. Penelitian ini menggunakan metode sampling non probabilitas. Penelitian ini menggunakan metode purposive sampling yaitu mengutamakan kriteria dan tujuan tertentu (Swarjana, 2016). Penelitian ini berlangsung di kelurahan Ragajaya, khusunya di RW 15, mulai tanggal 26 Januari hingga berakhir pada 13 Februari 2020.

Hasil dari tekanan darah responden sebelum dan sesudah intervensi kemudian diolah di SPSS. Uji analisis tekanan darah sistolik pada penelitian ini menggunakan Uji T Dependen/ paired t-test, karena data berdistribusi normal (Hastono, 2016). Uji analisis pada tekanan darah diastolik menggunakan Wilcoxon Test karena data tidak berdistribusi normal (Hastono, 2016). Apabila $P$ value $\leq 0,05$ maka JPMR memiliki efek terhadap penurunan tekanan darah, begitu pun sebaliknya (Hastono, 2016)

\section{HASIL PENELITIAN}

Pada Tabel 1 dijelaskan mengenai distribusi evaluasi intervensi JPMR yang dilakukan pada keluarga kelolaan.

Tabel 1. Distribusi Evaluasi Intervensi JPMR pada Keluarga Kelolaan

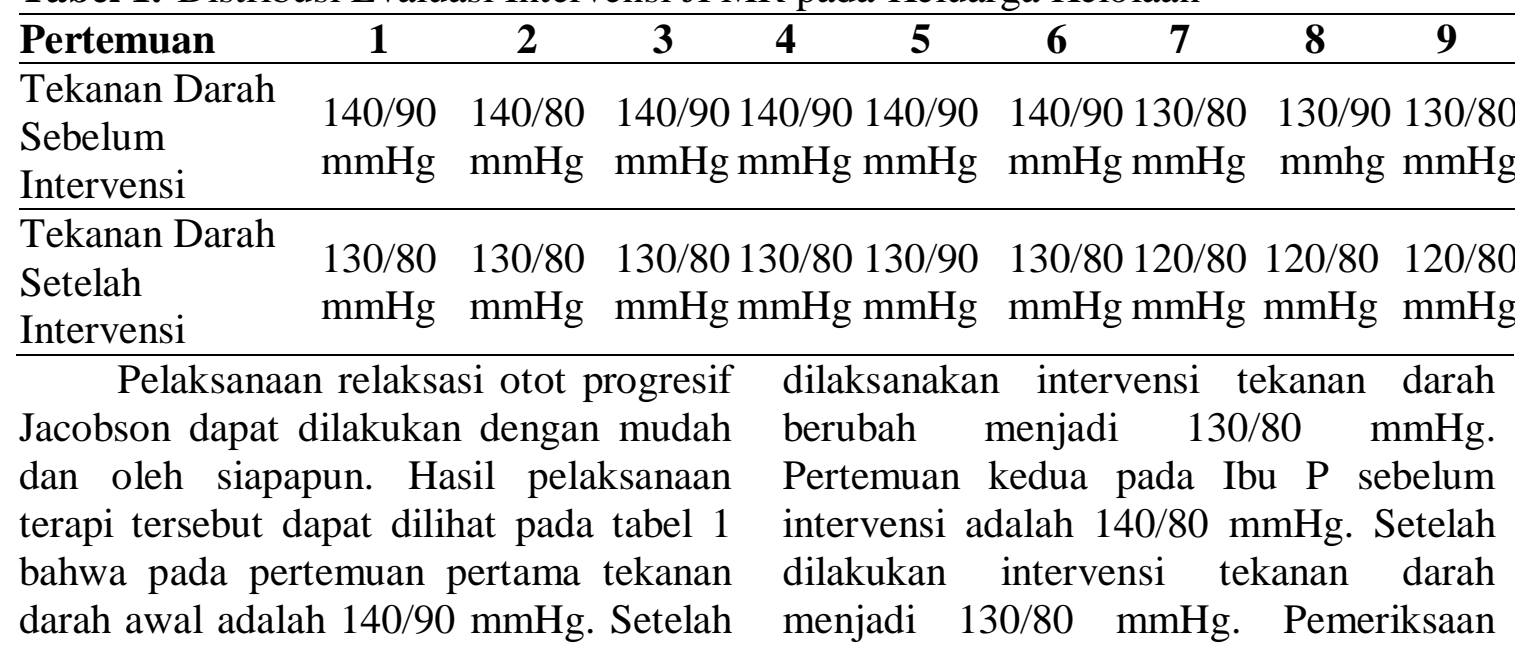


tekanan darah sebelum intervensi pada pertemuan ketiga sebesar 140/90 $\mathrm{mmHg}$. Tekanan darah hasil intervensi berada pada 130/80 mmHg. Tekanan darah sebelum dilakukan intervensi pada pertemuan kelima adalah 140/90 $\mathrm{mmHg}$. Tekanan darah setelah dilakukan tindakan intervensi adalah 130/80 $\mathrm{mmHg}$. Pada pertemuan keenam tekanan darah sebelum dilakukan terapi relaksasi JPMR adalah $140 / 90 \mathrm{mmHg}$ dan setelah dilakukan tindakan terapi adalah 130/90 mmHg. pertemuan ketujuh menunjukan bahwa tekanan darah sistolik sebelum dilakukan intervensi adalah 130/80 mmHg. Tekanan darah setelah dilakukan terapi adalah 120/80 mmHg. Tekanan darah sebelum intervensi pada pertemuan kedelapan adalah 130/90 mmHg, sedangkan pada pertemuan kesembilan adalah 130/80 mmHg. Tekanan darah setelah intervensi pada pertemuan kedelapan dan kesembilan adalah 120/80 $\mathrm{mmHg}$

Tabel 2. Distribusi Evaluasi Analisis Pengaruh Relaksasi Otot Progressif Jacobson Terhadap Tekanan Darah Sistolik Pada Keluarga Kelolaan dan Resume

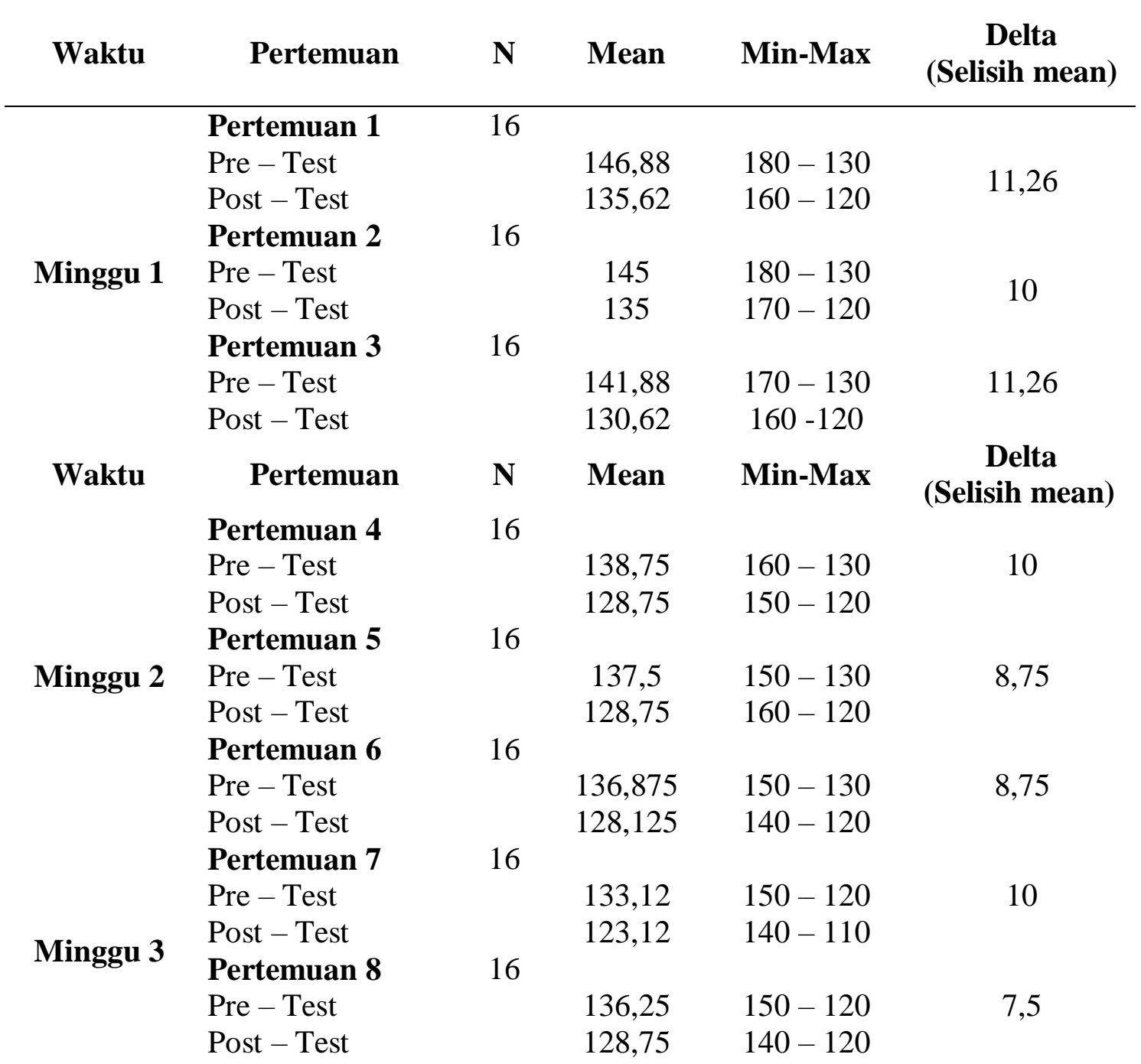




Pertemuan 9 16
Pre-Test
Post-Test
sudah mencapai kesembilan maka tekanan

Tabel 3. Distribusi Evaluasi Analisis Pengaruh Relaksasi Otot Progressif Jacobson Terhadap Tekanan Darah Diastolik Pada Keluarga Kelolaan dan Resume

\begin{tabular}{|c|c|c|c|c|c|}
\hline Waktu & Pertemuan & $\mathbf{N}$ & Mean & Min-Max & $\begin{array}{c}\text { Delta } \\
\text { (Selisih mean) }\end{array}$ \\
\hline \multirow{9}{*}{$\begin{array}{c}\text { Minggu } \\
1\end{array}$} & Pertemuan 1 & 16 & & & \multirow{3}{*}{6,25} \\
\hline & Pre - Test & & 90 & $80-100$ & \\
\hline & Post - Test & & 83,75 & $70-100$ & \\
\hline & Pertemuan 2 & 16 & & & \multirow{3}{*}{4} \\
\hline & Pre - Test & & 87,5 & $80-90$ & \\
\hline & Post - Test & & 83,5 & $80-90$ & \\
\hline & Pertemuan 3 & 16 & & & \multirow{3}{*}{5} \\
\hline & Pre - Test & & 89,375 & $80-100$ & \\
\hline & Post - Test & & 84,375 & $70-100$ & \\
\hline \multirow{9}{*}{$\begin{array}{c}\text { Minggu } \\
2\end{array}$} & Pertemuan 4 & 16 & & & \multirow{3}{*}{9,375} \\
\hline & Pre - Test & & 89,375 & $80-100$ & \\
\hline & Post - Test & & 80 & $70-90$ & \\
\hline & Pertemuan 5 & 16 & & & \multirow{3}{*}{6,25} \\
\hline & Pre - Test & & 88,125 & $80-100$ & \\
\hline & Post - Test & & 81,875 & $70-90$ & \\
\hline & Pertemuan 6 & 16 & & & \multirow{3}{*}{7,5} \\
\hline & Pre - Test & & 89,375 & $80-100$ & \\
\hline & Post - Test & & 81,875 & $70-90$ & \\
\hline \multirow{7}{*}{$\begin{array}{c}\text { Minggu } \\
\mathbf{3}\end{array}$} & Pertemuan 7 & 16 & & & \multirow{3}{*}{7,5} \\
\hline & Pre - Test & & 87,5 & $80-90$ & \\
\hline & Post - Test & & 80 & $70-90$ & \\
\hline & Pertemuan 8 & 16 & & & \multirow{4}{*}{6,25} \\
\hline & Pre - Test & & 86,25 & $80-90$ & \\
\hline & Post - Test & & 80 & $70-90$ & \\
\hline & Pertemuan 9 & 16 & & & \\
\hline
\end{tabular}




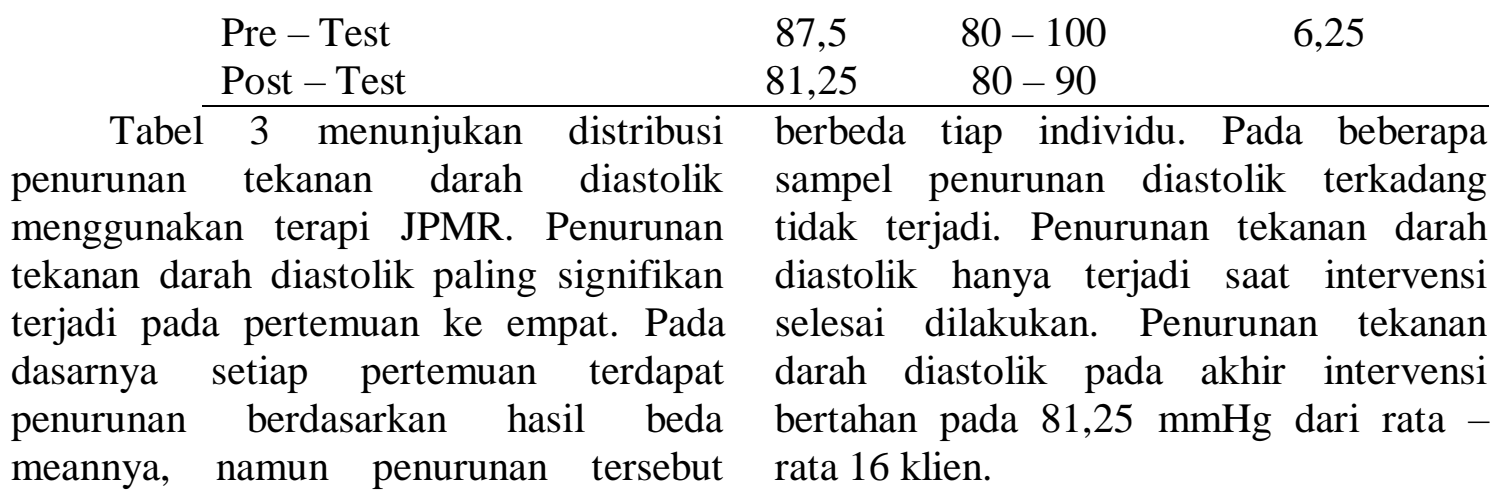

Tabel 4. Analisis Pengaruh Relaksasi Otot Progressif Jacobson terhadap Tekanan Darah Sistolik

\begin{tabular}{lccccc}
\hline \multicolumn{1}{c}{ Variabel } & N & Mean & $\begin{array}{c}\text { Std. } \\
\text { Deviasi }\end{array}$ & Std. Eror & P Value \\
\hline Tekanan Darah Sistolik & 16 & $\begin{array}{l}146,88 \\
\mathrm{mmHg}\end{array}$ & 14,477 & 3,619 & \\
$\begin{array}{l}\text { Sebelum Intervensi } \\
\text { Tekanan Darah Sistolik }\end{array}$ & 16 & $\begin{array}{l}128,77 \\
\mathrm{mmHg}\end{array}$ & 9,574 & 2,394 & 0,0000 \\
Sesudah Intervensi & & & & \\
\hline
\end{tabular}

Tabel 4 menunjukan analisa (Kesoema, dkk. 2016). Hasil dari pengaruh dari terapi relaksasi otot pengaruh berdasarkan Pvalue adalah progresif Jacobson terhadap perubahan <0,001 yang berarti bahwa relaksasi otot tekanan darah. Tekanan darah yang progresif Jacobson berpengaruh terhadap dihitung adalah tekanan darah sistolik. Tabel menunjukan rata - rata tekanan darah sistolik dari sebelum tindakan adalah 146,88 mmHg. Rata - rata tekanan darah sistolik setelah dilakukan terapi adalah 128,77 $\mathrm{mmHg}$. Standar deviasi dari masing - masing tekanan darah sistolik sebelum dan sesudah intervensi adalah 14,477 dan 9,574.

Peningkatan sistolik ini merupakan kondisi patofisiologis yang dapat menimbulkan masalah kardiovaskuler (Nikhra, 2017). Maka dari itu, JPMR dapat membantu dalam pengurangan tekanan darah sistolik bagi penderita hipertensi dan usia dewasa pada umumnya penurunan tekanan darah sistolik.

Relaksasi ini dianggap berpengaruh karena hasil dari Pvalue $<0,05$ atau $0,001<0,05$. Hasil ini sejalan dengan penelitian sebelumnya. Penelitian yang dilakukan oleh Khandaree pada tahun 2017 menunjukan bahwa dengan melakukan relaksasi otot progressif Jacobson dapat menurunkan tekanan darah sistolik. Penelitian tersebut menunjukan Pvalue sebesar $<0,001$. Diartikan bahwa dengan melakukan relaksasi otot progresif Jacobson maka penderita hipertensi dapat menurunkan tekanan darah sistoliknya. 
Tabel 5. Analisis Pengaruh Relaksasi Otot Progressif Jacobson terhadap Tekanan Darah Diastolik

\begin{tabular}{llllc}
\hline Variabel & N & Mean & Std. Deviasi & P Value \\
\hline $\begin{array}{l}\text { Tekanan Darah Diastolik } \\
\text { Sebelum Intervensi }\end{array}$ & 16 & $90 \mathrm{mmHg}$ & 6,325 & \\
$\begin{array}{l}\text { Tekanan Darah Diastolik } \\
\text { Sesudah Intervensi }\end{array}$ & 16 & $81,25 \mathrm{mmHg}$ & 3,416 & 0,001 \\
\end{tabular}

Tabel 5 menunjukan analisa pengaruh dari terapi relaksasi otot progresif Jacobson terhadap perubahan tekanan darah. Tekanan darah yang dihitung adalah tekanan darah diastolik. Tabel menunjukan rata - rata tekanan darah diastolik dari sebelum tindakan adalah $90 \mathrm{mmHg}$. Rata - rata tekanan darah diastolik setelah dilakukan terapi adalah $81,25 \mathrm{mmHg}$. Standar deviasi dari masing - masing tekanan darah sistolik sebelum dan sesudah intervensi adalah 6,325 dan 3,416. Hasil dari pengaruh berdasarkan Pvalue dengan menggunakan perhitungan Wilcoxon di SPSS adalah 0,001 yang berarti bahwa relaksasi otot progresif Jacobson berpengaruh terhadap penurunan tekanan darah diastolic.

\section{PEMBAHASAN}

Penelitian ini dilakukan kepada 16 responden dengan masalah kesehatan berupa adanya peningkatan dari tekanan darah. Intervensi yang diberikan sesuai dengan penelitian yang dilakukan oleh Khandare, dkk (2017). Penelitian ini menyatakan bahwa dengan melakukan relaksasi otot progresif Jacobson, maka tekanan darah akan menurun pada penderita hipertensi (Khandare dkk., 2017).

Hipertensi terjadi karena adanya curah jantung dikali dengan resistensi perifer atau bisa disebut sebagai tekanan dari arteri perifer. Berdasarkan uraian tersebut maka dapat dijelaskan bahwa tekanan darah yang tinggi terjadi karena adanya peningkatan curah dari jantung serta terdapat tahanan pada pembuluh darah perifer. Peningkatan curah jantung terjadi diakibatkan karena adanya penumpukan cairan atau disebut preload (Pikir dkk., 2015).

Curah jantung meningkat juga dapat terjadi karena adanya peningkatan kontraktilitas jantung akibat dari perubahan sistem saraf pada jantung. Telah banyak studi menunjukan bahwa peningkatan curah jantung yang bersifat kronik pada awalnya memang meningkatkan tekanan darah sebagai bentuk kompenasasi, namun setelah beberapa hari resistensi perifer akan meningkat dan curah jantung akan menurun kembali ke nilai basal awal (Pikir dkk., 2015). Apabila tidak adanya tindakan dalam penurunan tekanan darah, maka dapat menyebabkan permasalahan serius bagi tubuh.

Beberapa komplikasi yang dapat muncul akibat adanya peningkatan tekanan darah. Komplikasi tersebut diantaranya adalah nyeri dada, stroke, serangan jantung, hingga gagal ginjal (WHO, 2019). Komplikasi ini dapat berpengaruh terhadap kualitas hidup penderita. Penatalaksanaan perlu dilakukan untuk mengurangi kejadian komplikasi. Penatalaksanaan yang dapat dilakukan penderita hipertensi adalah 
dengan rutin mengkonsumsi obat didampingi dengan tindakan non farmakologis (Pikir dkk., 2015).

Salah satu bentuk tindakan nonfarmakologis untuk mengurangi peningkatan tekanan darah yaitu dengan melakukan relaksasi otot progresif Jacobson (Kesoema, dkk. 2016). Relaksasi otot progresif Jacobson merupakan sebuah bentuk relaksasi yang memiliki gerakan mengencangkan otot kemudian merileksasikan otot (Khandare, dkk, 2017). Gerakan relaksasi otot progresif Jacobson merupakan bentuk relaksasi yang berurutan (Kesoema, dkk. 2016). Penggunaan relaksasi otot progresif Jacobson dipilih karena tindakan ini mudah untuk dilakukan di rumah (Khandare, dkk, 2017). Pengguna relaksasi otot prgresif Jacobson akan merasakan perbedaan ketika otot yang pada awalnya ditegangkan yang kemudian di rilekskan. Relaksasi ini akan selesai bila setiap langkah telah telah dilakukan (Kesoema, dkk. 2016).

JPMR dilakukan sebanyak 9 kali pertemuan (tiga kali seminggu dalam tiga minggu), dengan durasi $20-30$ menit pada setiap pertemuan. Gerakan pada relaksasi JPMR berjumlah 17 gerakan yang SOP diambil dari Guy's \& Thomas, (2019). Gerakan dilakukan secara berurutan, dimana tiap responden diberikan satu kali intervensi lengkap yang didahului dan diakhiri dengan tarik napas dalam terlebih dahulu. Tarik napas dalam dilakukan sebanyak tiga kali inspirasi dan ekspirasi yang dilakukan sebelum dan sesudah dari tindakan JPMR.

Hasil penelitian telah menunjukan bahwa adanya efektifitas dari relaksasi otot progresif Jacobson terhadap tekanan darah sistolik dan diastolik. Pada hasil intervensi untuk tekanan darah sistolik didapatkan Pvalue sebesar $<0,001$ yang berarti bahwa relaksasi otot progresif Jacobson berpengaruh terhadap penurunan tekanan darah sistolik. Hasil dari pengaruh JPMR terhadap tekanan darah diastolik berdasarkan Pvalue dengan menggunakan perhitungan Wilcoxon di SPSS adalah 0,001 yang berarti bahwa relaksasi otot progresif Jacobson berpengaruh terhadap penurunan tekanan darah diastolik. Meskipun pada hasil secara rata - rata didapatkan penurunan diastolik, namun berdasarkan intervensi secara perminggu didapatkan ada yang tidak mengalami penurunan pada diastoliknya. Penurunan diastolik dapat tidak terjadi karena pada usia responden yaitu diantara 40 hingga 55 tahun tekanan diastolik cendurung menetap (Nikhra, 2017).

Kondisi ini dapat menjadi alasan mungkin saat dilakukan intervensi tekanan diastolik dalam kondisi normal yang menyebabkan penurunan tidak terjadi. Situasi ini memang sesuai dengan tujuan dari terapi JPMR yaitu untuk menormalkan kondisi pembuluh darah dengan gerakan penenangan diikuti relaksasi, yang apabila pembuluh darah sudah stabil maka perubahan tidak terjadi (Kesoema, dkk. 2016).

Hasil penelitian ini sejalan dengan Kesoema bersama dengan tim pada tahun 2016. Pada penelitian tersebut perhitungan SPSS menunjukan Pvalue dari antara pre hari pertama intervensi dengan post hari terakhir intervensi pada perlakuan JPMR adalah <0,001 (Kesoema, dkk., 2016). Hasil penelitian ini juga sejalan dengan penelitian yang dilakukan oleh Shinde dan tim pada tahun 2013. Pada penelitian ini keseluruhan responden memiliki hasil Pvalue <0,005 untuk tekanan darah sistolik dan diastolik hasil ini menunjukan bahwa dengan melakukan 
JPMR maka penurunan tekanan darah baik sistolik dan diastolikk dapat terjadi pada penderita hipertensi (Shinde dkk., 2013). Penelitian ini juga sejalan dengan oleh Khandare bersama tim pada tahun 2017. Hasil dari intervensi penelitian tersebut menunjukan Pvalue sebesar $<0,001$ (Khandare, dkk, 2017).

Pemberian tindakan JPMR pada keluarga memiliki beberapa faktor pendukung keberhasilan intervensi. Faktor pendukung ini berdasarkan hasil pemantauan selama intervensi oleh perawat kepada responden. Kepatuhan serta keinginan untuk mengurangi tekanan darah menjadi kemudahan bagi perawat untuk menyampaikan informasi terapi (Shinde, dkk, 2013). Jangan memaksakan responden yang tidak mampu serta mau melakukan intervensi, karena intervensi tidak akan berefektif (Shinde, dkk, 2013).

Komunikasi yang baik perlu diterapkan kepada keseluruhan responden. Penjelasan mengenai terapi yang diberikan harus sederhana, mudah dimengerti, dan menimbulkan keinginan untuk melakukan tindakan. Kesadaran responden mengenai penyakit yang dialami serta pencegahan komplikasi dapat mempermudah perawat untuk memberikan informasi terapi ini. Gerakan yang sistematis membantu perawat untuk mengingatkan kepada responden urutan dari tindakan.

\section{KESIMPULAN DAN SARAN}

Efektifitas dari terapi JPMR bukan hanya dirasa oleh keluarga kelolaan, namun terapi ini juga berefektif bagi keluarga resume lainnya. Keluarga kolalaan utama serta hampir seluruh keluarga resume merupakan penderita hipertensi dalam kategori pra hipertensi serta hipertensi tingkat I. Berdasarkan hasil evaluasi yang telah dilakukan pada 16 klien resume serta kelolaan telah ditemukan efektifitas dari intervensi JPMR. Evaluasi tersebut mendapatkan Pvalue <0,001 pada penurunan tekanan sistolik dan diastolik. Hasil Pvalue < 0,05, maka dapat disimpulkan bahwa terapi JPMR berefektif terhadap penurunan tekanan darah pada pra hipertensi serta hipertensi tingkat 1 . Terapi ini memang terbukti dapat menjadi terapi komplementer hipertensi. perlu diperhatikan bahwa pemakaian obat antihipertensi tetap harus dilakukan. Obat antihipertensi merupakan terapi farmakologi yang harus diberikan dan rutin diminum oleh penderita hipertensi (Pikir dkk., 2015). Terapi ini hanya sebagaI terapi pendamping.

Keluarga yang memiliki anggota dengan permasalahan hipertensi dapat melakukan terapi JPMR. Motivasi terus keluarga yang mengalami hipertensi untuk melakukan terapi dibarengi dengan obat. Jangan paksakan diri apabila sedang tidak mampu melaksanakan terapi.

Perawat perlu membangun Bina hubungan saling percaya yang harus dilakukan setiap pertemuan untuk mencegah tindakan ketidakooperatif dari responden. Perawat harus memberikan penjelasan mengenai terapi secara sederhana, mudah dimengerti, dan menimbulkan keinginan untuk melakukan tindakan.

$$
\text { Peneliti selanjutnya dapat }
$$
mengembangkan terapi JPMR yang lebih ringkas namun efektif. Peneliti selanjutnya juga dapat mengembangkan SOP agar tindakan mudah dilakukan oleh semua orang.

\section{DAFTAR RUJUKAN}

American Heart Association. (2016). 
What Is High Blood Pressure?.

C, K., Grover, S., Rabkin, S. W., Gordon, W., Howlett, J. G., Lindsay, P., ... Wein, T. H. (2018). Hypertension Canada's 2018 Guidelines for Diagnosis, Risk Assessment, Prevention, and Treatment of Hypertension in Adults and Children. Canadian Journal of Cardiology. Canadian Cardiovascular Society.

Guy's, \& Thomas, S. (2019). Jacobson 's progressive relaxation technique.

Hastono, S. P. (2016). Analisis Data pada Bidang Kesehatan. Jakarta: Rajawali Pers.

Hernilawati. (2013). Pengantar Ilmu Keperawatan Komunitas. (Amirullah, Ed.) (Edisi Pertama). Penulis dan Penerbit Pustaka As Salam:Takalar.

Kementerian Kesehatan Republik Indonesia. (2018). Hasil Utama RISKESDAS 2018.

Kementrian Kesehatan Republik Indonesia. (2013). Riset Kesehatan Dasar.

Kementrian Kesehatan Republik Indonesia. (2019). Hari Hipertensi Dunia 2019: "Know Your Number, Kendalikan Tekanan Darahmu dengan CERDIK."

Kesoema, T. A., Chasani, S., \& Handoyo, R. (2016). Comparison Between Taichi Chuan And Jacobson's Progressive Muscular Relaxation In
Decreasing Cortisol Concentrasion On Pre-Hypertension Patient's, 12(1), 52-59.

Khandare, S., Sabuwala, M., Palekar, T. J., \& Kuma, V. (2017). Effect Of Jacobson's Relaxation Technique On Clinical Parameters In Hypertension Patients, 6(6), 12581263.

Nikhra, V. (2017). Aging Heart: Recent Research and Concepts. Gerontology \& Geriatrics Studies, 1(1), 1-11.

Pikir, B. S., Aminuddin, M., Subagjo, A., Dharmadjati, B. B., Suryawan, I. G. R., \& P, J. N. E. (Eds.). (2015). Hipertensi Manajemen Komprehensif (Vol. 1). Surabaya: University Press: Airlangga.

Shinde, N., Shinde, K., Khatri, S., \& Hande, D. (2013). Immediate Effect of Jacobson's Progressive Muscular Relaxation in Hypertension. Scholars Journal of Applied Medical Sciences, 1(2), 80-85.

Stafford, R. S., Taler, S. J., Thomas, R. J., Williams, K. A., Williamson, J. D., \& Wright, J. T. (2018). 2017 ACC / AHA / AAPA / ABC / ACPM / AGS / APhA / ASH / ASPC / NMA / PCNA Guideline for the Prevention, Detection, Evaluation, and Management of High Blood Pressure in Adults, 71(19).

Swarjana, I. K. (2016). Statistik Kesehatan. (A. A. C, Ed.) (1st ed.). Yogyakarta: Andi. 
WHO. (2019). Key facts Why is hypertension an important issue in low- and middle-income. 